\title{
Exposure to arsenic induces histomorphological alterations in testis of rabbits
}

\author{
Riaz Hussain Pasha1 ${ }^{*}$, Anas Sarwar Qureshi², Adnan Ali ${ }^{3}$, Saif-Ur-Rehman ${ }^{4}$, Muhammad Akram Khan ${ }^{5}$ \\ ${ }^{1}$ Department of Veterinary Biomedical Sciences (Histology), Faculty of Veterinary and Animal Sciences, PMAS-Arid \\ Agriculture University, Rawalpindi, Pakistan \\ ${ }^{2}$ Department of Anatomy, Faculty of Veterinary Science, University of Agriculture, Faisalabad, Pakistan \\ ${ }^{3}$ Food and Agriculture Organization (FAO) Project, Technical Unit-Building Disaster Resilience in Pakistan, Islamabad, \\ Pakistan \\ ${ }^{4}$ Department of Parasitology and Microbiology, Faculty of Veterinary and Animal Sciences, PMAS-Arid Agriculture \\ University, Rawalpindi, Pakistan \\ ${ }^{5}$ Department of Veterinary Pathology, Faculty of Veterinary and Animal Sciences, PMAS-Arid Agriculture University, \\ Rawalpindi, Pakistan
}

\begin{tabular}{|c|c|}
\hline $\begin{array}{l}\text { Received: } \\
\text { March 29, } 2021\end{array}$ & \multirow{4}{*}{$\begin{array}{l}\text { Abstract } \\
\text { With the expansion and development of industrial technology, frequent application of } \\
\text { various synthetic chemicals like pesticides, insecticides and arsenic has led to } \\
\text { contamination of both aquatic and terrestrial ecosystem across the globe. Among } \\
\text { different synthetic chemicals arsenic poisoning has become a huge threat to ground } \\
\text { water in many parts of the world. Therefore, this study was planned to examine the } \\
\text { adverse effects of sodium arsenite on the morphology (gross and microscopic } \\
\text { structure) of testis in rabbits. A total of } 20 \text { adult male rabbits were procured and } \\
\text { randomly divided into two groups. Group (A) served as control and rabbits in group } \\
\text { (B) were exposed to sodium arsenite orally (@ dose of } 10 \mathrm{mg} / \mathrm{kg} / \text { day for a period } 60 \\
\text { days. Results indicated significant (p<0.05) lower values of testicular weight, scrotal } \\
\text { length and width, testicular volume, volume occupied by } 10 \text { seminiferous tubules and } \\
\text { volume of the individual Leydig cells in treated rabbits. The exposure induced } \\
\text { degenerative changes in testis including wavy contour of seminiferous tubules, } \\
\text { vacuolization in the germinal epithelium and germ cell loss was recorded in the } \\
\text { treated group. In conclusion, it was observed that arsenic may induce male } \\
\text { reproductive effects by negatively affecting the testicular volume, Leydig cell } \\
\text { population and volume of the Leydig cells. }\end{array}$} \\
\hline $\begin{array}{l}\text { Accepted: } \\
\text { April 30, } 2021\end{array}$ & \\
\hline $\begin{array}{l}\text { Online First: } \\
\text { January 02, } 2022\end{array}$ & \\
\hline $\begin{array}{l}\text { Published: } \\
\text { January 09, } 2022\end{array}$ & \\
\hline & Keywords: Arsenic toxicity, Rabbit testis, Histomorphology, Pakistan \\
\hline & \\
\hline & $\begin{array}{l}\text { Pasha RH, Qureshi AS, Ali A, Rehman SU and Khan MA, 2022. Exposure to arsenic } \\
\text { induces histomorphological alterations in testis of rabbits. Asian J. Agric. Biol. } \\
\text { 2022(1): 202104178. DOI: https://doi.org/10.35495/ajab.2021.04.178. }\end{array}$ \\
\hline
\end{tabular}

This is an Open Access article distributed under the terms of the Creative Commons Attribution 3.0 License. (https://creativecommons.org/licenses/by/3.0), which permits unrestricted use, distribution, and reproduction in any medium, provided the original work is properly cited.

\section{Introduction}

Various agricultural and industrial processes persistently release different synthetic compounds or waste materials into natural water bodies leading to deleterious effects on both public health and aquatic 
life (Sharaf et al., 2020; Ghaffar et al., 2020). Monitoring, identification and management of different chemicals / pollutants is of vital importance and crucial to reduce the toxic effects on target and non-target exposed organisms (Latif et al., 2020; Gul et al., 2020). Water is an imminent source of life on earth and water pollution has become a global threat to human and animal health. In Pakistan, there are numerous imminent origin to pollute ground water. Chemical and biological contagion of drinking water has been documented all over the country (Tahir and Bhatti, 1994; Kahlown et al., 2004; Raza et al., 2017). Such contagion is accredited to effluence from sewage system, intermittent water supply, and shallow water tables, herbicides, floods, fungicides, untreated municipal waste are extremely hazardous for drinking water (Ghaffar et al., 2018; Hussain et al., 2020). Owing to swift industrialization and overwhelming civilization, the heavy metal toxicity is a leading health condition in the world (Ghaffar et al., 2016; Rehman, 2018). The evaluation of the heavy metals exposure has become central area of research in the medical related field since last decade of the nineteenth century. Metals have been reported to be negatively affect the process of spermatogenesis in experimental animals (Verstraeten et al., 2008; Naz et al., 2020). Due to continual nature and affinity to accumulate in organisms, heavy metals are considered as strong biological poisons (Kamble and Muley, 2000; Imran et al., 2020). Among different heavy metals, arsenic is metabolically multifarious and as a result perilous to health. The principal utilization of this heavy metal is as preservative, insecticide, pesticide, herbicide, algaecide, growth promoter, in some alloys and electronic industry. Arsenic may be released into the environment through explosions, rocks and soil. It contaminate the air due to coal combustion, manufacturing waste and use of agriculture pesticides containing arsenic (DEFRA and EA, 2002).

Recent studies have reported arsenic poisoning as a massive epidemic in most of the globe and particularly in Pakistan due to arsenic ground water contamination and toxicity (Malik et al., 2010; Samrana et al., 2017; Shaikh et al., 2018; Sohail et al., 2019). Epidemiological investigations conducted in the globe including Bangladesh, Taiwan, China and Ukraine have exposed that arsenic contaminated food and water is the major cause of reproductive disorders (Yang et al., 2003). Most of the heavy metals are reported as classical testicular toxicants
(Sharma and Garu, 2011). Without any doubt, testes are the major organs for male sexual development and fertility. Male reproductive health upshot of arsenic was first studied in mice, then in fishes (Shukla and Pandey, 1984). Arsenic exposure in experimental rats has revealed impairment of spermatogenesis, oxidative hassle and genotoxic effects on the testis (Biswas et al., 2006; Chang et al., 2007). Many workers have reported the arsenic reprotoxicity in experimental rat shown by the reduction in testicular and other sex organ mass, necrotic changes in the testicular tissue, degenerative changes in the germ cells and oxidative stress (Chinoy et al., 2004; Ahmad et al., 2008; Sanghamitra et al., 2008; Mukherjee and Mukhopadhyay, 2009). Keeping in view the persistent exposure of general population to arsenic through ground water in Pakistan (Shahid et al., 2017; Podgorski et al., 2017; Samrana et al., 2017; Shaikh et al., 2018; Sohail et al., 2019) and lack of significant male reproductive toxicity data on morphology of testis in the literature, current research plan was designed to investigate the histomorphometric and anatomical testicular tissue damage after induced arsenic poising in rabbits in the natural ecology of Pothohar area of Pakistan.

\section{Material and Methods}

In order to circumvent experimental animal distress, the methodology was designed conforming to the guiding principle approved by the animal welfare ethical committee of the PMAS-Arid Agriculture University.

\section{Experimental animals}

Twenty adult healthy male rabbits were kept in cages in the Animal House of Department of Biomedical Sciences, Faculty of Veterinary and Animal Sciences, PMAS-Arid Agriculture University Rawalpindi. The rabbits were allowed to acclimatize for duration of three weeks before the commencement of the experiment.

\section{Treatment regime}

After acclimatization period, the rabbits were divided at random into two groups ( $\mathrm{n}=10$ for each group); group A (control) was kept as control, group B (Sod. Arsenite treated) was kept as sodium arsenite (@ dose of $10 \mathrm{mg} / \mathrm{kg} /$ day), the drug administration was given orally for 60 days (Zubair et al., 2014). 


\section{Body and testes weight (gms)}

Body weight and testis weight was measured before and after the experimental period. Before the start of experiment and at the end of investigational period, the animals were euthanized and testes were collected and weighed individually with the electrical balance.

\section{Scrotal biometry of testis}

Scrotal length $(\mathrm{cm})$ and width $(\mathrm{cm})$ of the testis of experimental animals before the start and at the end of the experimental period of all the groups was measured and recorded.

\section{Histomorphology}

Small pieces of the testicular tissue were taken from the mid of the testis and fixed in Bouin's solution till processed for paraffin embedding technique (Bancroft and Gamble, 2008). Tissue sectioning was performed by rotary microtome, $5 \mu \mathrm{m}$ thick sections were stained with hematoxylin and eosin for histomorphometric studies under light microscope: Testicular volume was determined by using the formula described by (Johnson and Neaves, 1981):

Testicular volume $\left(\mathrm{cm}^{3}\right)=$ testis weight $(\mathrm{g}) /$ Testis density (1.052)

The volume occupied by 10 seminiferous tubules cross section was calculated by the formula described by Moura and Erickson (1997):

$\mathrm{V}_{\mathrm{st}}=\pi \times \mathrm{h} \times\left(\mathrm{d}^{2} / 4\right)$, where $\mathrm{h}$ was the section thickness $(5 \mu \mathrm{m})$, and $\mathrm{d}$ was tubular diameter $(\mu \mathrm{m})$. The volume of an individual Leydig cell was determined by the formula: $L c=(4 / 3) \times \pi \times D^{3}$ where $D$ is the average diameter $(\mu \mathrm{m})$ of Leydig cells

\section{Statistical analysis}

The data were subjected to statistical analysis by using Two-way ANOVA followed by student t-test to find out the significance difference between different treatments maintained under controlled laboratory conditions.

\section{Results and Discussion}

The main objective of this experiment was to study the macro and microscopic changes in the testis of rabbits which may leads to reproductive health hazards due to the arsenic poisoning, and may affect the reproductive efficiency and hence the animal production. The experimental rabbits were randomly divided into two groups; group-A (control) was kept as control, group-B (Sod. Arsenite treated) was kept as sodium arsenite (@ dose of $10 \mathrm{mg} / \mathrm{kg} /$ day) treated. The data of mean total body weight and testicular weight was recorded before and after the experimental period.

\section{Body weight}

Initial mean body weight of the rabbits of control and treated groups was recorded as $905.45 \pm 48.51 \mathrm{gms}$ and $915.00 \pm 20.15 \mathrm{gms}$ and at the end of experiment the final mean body weight was recorded as $910.50 \pm 50.14$ gms and $900.14 \pm 48.12$ gms respectively (Table 1). There was non-significant difference in body weights of all the rabbits among two groups.

Table-1: Comparison of body weight (gms), testicular weight (gms), scrotal length $(\mathrm{cm})$ and scrotal width (cm) of the experimental rabbits

\begin{tabular}{|c|c|c|c|c|}
\hline \multirow{2}{*}{ Parameters } & \multicolumn{4}{|c|}{ Treatment } \\
\cline { 2 - 5 } & \multicolumn{2}{|c|}{ Before } & After & Mean \pm SD \\
\hline \multirow{2}{*}{ Body Weight (gms) } & Control & $905.45 \pm 48.51$ & $910.50 \pm 50.14$ & $900.40 \pm 31.80$ \\
\cline { 2 - 5 } & $\begin{array}{c}\text { Treated } \\
\text { (@ dose of 10mg/kg/day) }\end{array}$ & $915.00 \pm 20.15$ & $900.14 \pm 48.12$ & $914.50 \pm 14.61$ \\
\hline \multirow{2}{*}{$\begin{array}{c}\text { Paired testicular } \\
\text { Weight (gms) }\end{array}$} & \begin{tabular}{c} 
Control \\
Treated \\
\cline { 2 - 5 } (@ dose of 10mg/kg/day)
\end{tabular} & $2.48 .25 \pm 35.51$ & $2.52 \pm 43.12$ & $2.51 \pm 30.10$ \\
\hline \multirow{2}{*}{ Scrotal Length (cm) } & Control & $2.30 .20 \pm 21.21$ & $1.02 \pm 33.10$ & $1.89 \pm 12.21$ \\
\cline { 2 - 5 } & $\begin{array}{c}\text { Treated } \\
\text { (@ dose of 10mg/kg/day) }\end{array}$ & $2.23 \pm 12.15$ & $1.35 \pm 30.16$ & $1.76 \pm 44.11$ \\
\hline \multirow{2}{*}{ Scrotal Width (cm) } & Control & $1.15 .10 \pm 31.11$ & $1.55 \pm 12.18$ & $1.35 \pm 32.10$ \\
\cline { 2 - 5 } & $\begin{array}{c}\text { Treated } \\
\text { (@ dose of 10mg/kg/day) }\end{array}$ & $1.18 \pm 32.12$ & $0.88 \pm 10.19$ & $0.99 \pm 37.21$ \\
\hline
\end{tabular}




\section{Testicular weight}

The sodium arsenite treated group of the rabbits was recorded as having significantly $(\mathrm{p}<0.05)$ low testicular weight $(1.89 \pm 12.21 \mathrm{gms})$ as compared to the testicular weight of control rabbits $(2.51 \pm 30.10$ gms) (Table 1).

\section{Scrotal length and width $(\mathrm{cm})$}

The scrotal length $(\mathrm{cm})$ was recorded as 2.30.20 $\pm 21.21 \mathrm{~cm}$ and $2.25 \pm 35.10 \mathrm{~cm}$ before and after the experiment in control group of experimental animal while the same parameter (length) was documented as $2.23 \pm 12.15 \mathrm{~cm}$ and $1.35 \pm 30.16 \mathrm{~cm}$ before and after the experiment in treated group of the rabbits (Table 1). Statistical analysis revealed a significant $(\mathrm{p}<0.05)$ decrease in the scrotal length in the arsenic treated rabbits.

The scrotal width $(\mathrm{cm})$ was recorded as $1.15 .10 \pm 31.11 \mathrm{~cm}$ and $1.55 \pm 12.18 \mathrm{~cm}$ before and after the experiment in control group while the same parameter was measured as $1.18 \pm 32.12 \mathrm{~cm}$ and $0.88 \pm 10.19 \mathrm{~cm}$ before and after the experiment in treated group of the rabbits (Table 1). Statistical analysis revealed a significant $(\mathrm{p}<0.05)$ decrease in this parameter in the arsenic treated rabbits.

Testicular volume and volume occupied by 10 seminiferous tubules $\left(\mathrm{cm}^{3}\right)$

The testicular volume $\left(\mathrm{cm}^{3}\right)$ was recorded as $1.23 \pm 12.09 \mathrm{~cm}^{3}$ and $0.70 \pm 22.10 \mathrm{~cm}^{3}$ in control and arsenic treated rabbits respectively while the volume occupied by 10 seminiferous tubules was documented as $0.55 \pm 11.15 \mathrm{~cm}^{3}$ and $0.23 \pm 10.19 \mathrm{~cm}^{3}$ in control and treated groups of the experimental animals respectively (Table 2). Statistical analysis revealed a significant $(\mathrm{p}<0.05)$ decrease in both parameter in the arsenic treated rabbits.

Volume of individual leydig cell $\left(\times 10^{-12} \mathrm{ml}\right)$

The volume of individual Leydig cell $\left(\times 10^{-12} \mathrm{ml}\right)$ was recorded as $1,889.10 \pm 250.49\left(\times 10^{-12} \mathrm{ml}\right)$ and $1,001.11 \pm 249.10\left(\times 10^{-12} \mathrm{ml}\right)$ in control and arsenic treated rabbits respectively (Table 2). Statistical analysis revealed a significant $(\mathrm{p}<0.05)$ decrease of individual Leydig cell volume in the arsenic treated rabbits as compared to the control group of the experimental animals.
Table-2: Comparison of the testicular volume $\left(\mathrm{cm}^{3}\right)$ and volume occupied by 10 seminiferous tubules $\left(\mathrm{cm}^{3}\right)$ and Volume of the Individual Leydig cell $\left(\times 10^{-12} \mathrm{ml}\right)$ of the experimental rabbits

\begin{tabular}{|l|c|c|c|}
\hline \multicolumn{1}{|c|}{ Parameters } & Control & Treated & Mean \pm SD \\
\hline $\begin{array}{l}\text { Testicular Volume } \\
\left(\mathbf{c m}^{\mathbf{3}}\right)\end{array}$ & $1.23 \pm 12.09$ & $0.70 \pm 22.10$ & $1.05 \pm 12.40$ \\
\hline $\begin{array}{l}\text { Volume occupied by } \\
(\mathbf{1 0}) \text { seminiferous } \\
\text { tubules }\end{array}$ & $0.55 \pm 11.15$ & $0.23 \pm 10.19$ & $0.38 \pm 21.14$ \\
\hline $\begin{array}{l}\text { Volume of the } \\
\text { individual Leydig cell } \\
\left(\mathbf{x 1 0}^{-12} \mathbf{m l}\right)\end{array}$ & $\begin{array}{l}1,889.10 \pm 2 \\
50.49\end{array}$ & $\begin{array}{l}1,001.11 \pm 2 \\
49.10\end{array}$ & $\begin{array}{c}1,545.20 \pm 22 \\
7.30\end{array}$ \\
\hline
\end{tabular}

\section{Histopathological alterations in the testis}

The testes of control group showed normal appearance of the seminiferous tubules having normal arrangement of the germinal epithelial cells including sertoli cells, spermatogonia and spermatozoa (Fig. 1 and 3). Whoever histological observations of experimental group revealed various abnormal changes like intraepithelial vacuolization, signs of necrosis, reduced number of spermatogenic cells, rupturing of germinal epithelium and degenerative cells were observed in the testis of treated group of rabbits (Fig 2 and 4). The volume of seminiferous tubules and Leydig cells was also decreased significantly.

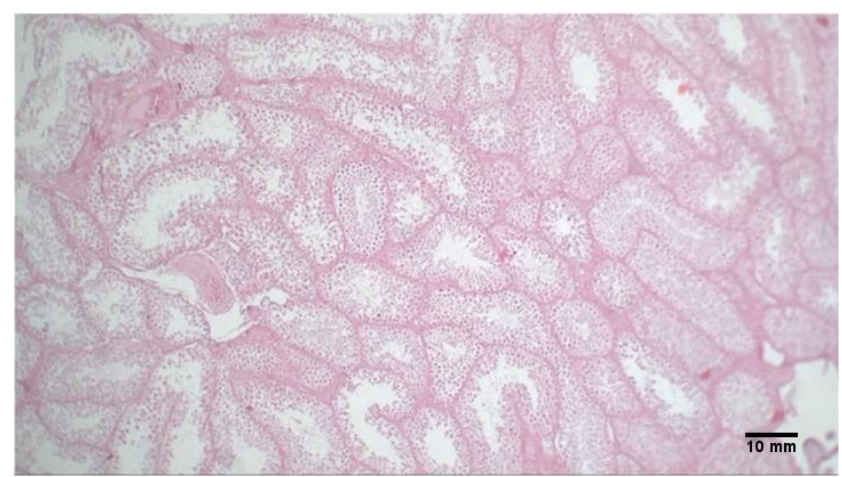

Figure-1: Photomicrograph of testis showing the cross section of seminiferous tubules from Group -A (Control), showing normal seminiferous tubules with intact germinal epithelium (black arrow), tubular lumen (A), and interstitium (C). H\&E stain $10 \mathrm{X}$ 


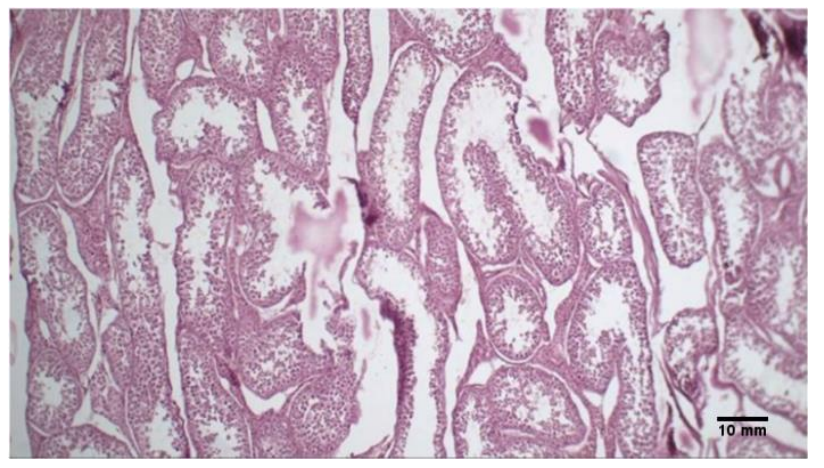

Figure-2: Photomicrograph of testis showing the cross section of seminiferous tubules from Group -B (Treated), exposing degenerated cells in the lumen of tubules (A), and vacuolization in the germinal epithelium (black arrow). H\&E stain $10 \mathrm{X}$

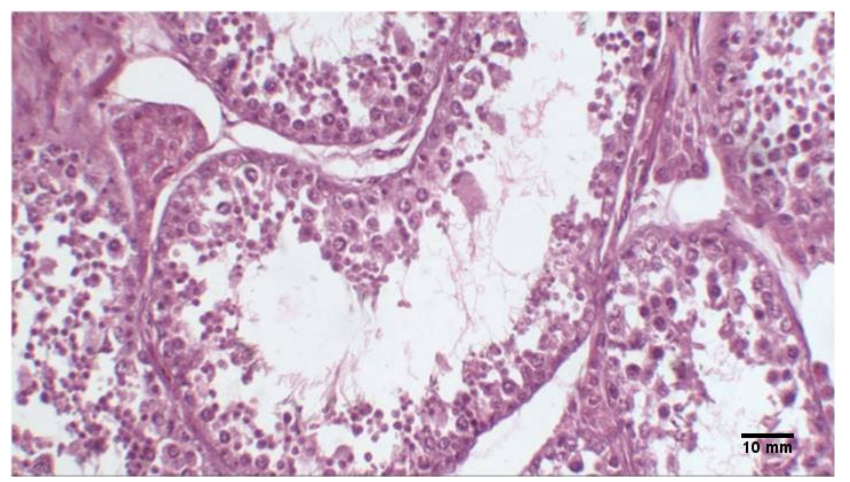

Figure-3: Photomicrograph of testis showing the cross section of seminiferous tubules from Group -A (Control), showing normal seminiferous tubules with intact germinal epithelium (A), tubular lumen (B), and Leydig cells (black arrow). H\&E stain $40 \mathrm{X}$

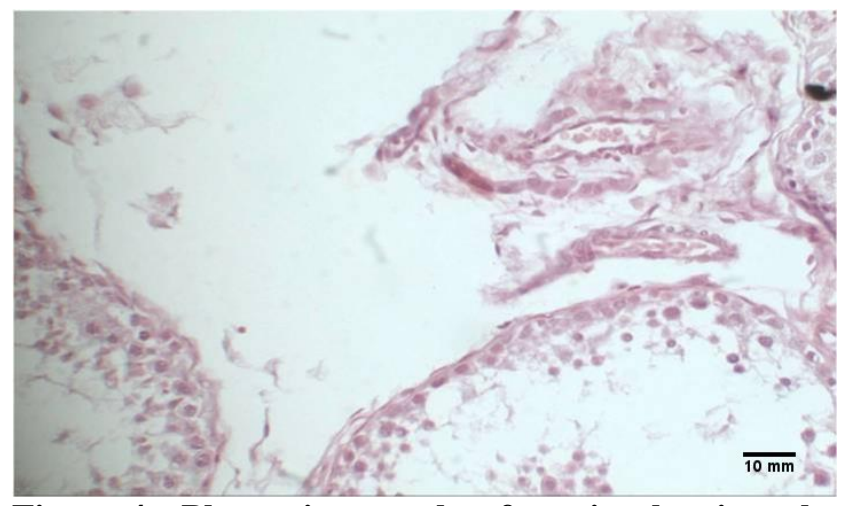

Figure-4: Photomicrograph of testis showing the cross section of seminiferous tubules from Group -B (Treated), revealing degenerated cells in the lumen of tubules (A), interstitium (B) and vacuolization in the germinal epithelium (black arrow) . H\&E stain $40 \mathrm{X}$
The present study was designed to explore the anatomic toxic effects of arsenic on the testicular tissues after induced arsenic poisoning in rabbits. This study revealed no significant difference among the body weights of the control and the arsenic treated rabbits which confirm the results of previous studies (Zubair et al., 2014; Sanghamitra et al., 2008). However, another study reported significantly decreased body weight in the arsenic treated rabbits (Sarkar et al., 2003). The divergence noted above from the values reported by Chang may be accredited to the duration or dosage of the treatment.

The sodium arsenite treated group of the rabbits was recorded as having significantly $(\mathrm{p}<0.05)$ low testicular weight $(1.89 \pm 12.21 \mathrm{gms})$ as compared to the testicular weight of control rabbits $(2.51 \pm 30.10$ gms), these finding are in accord with the previous findings (Zubair et al., 2014; Sanghamitra et al., 2008).

This experiment showed the significant $(p<0.05)$ decrease in the scrotal length and scrotal width in the arsenic treated rabbits as compared to the control group of the rabbits. Testicular mass and scrotal size is an important index of the testicular toxicity and damage to the germ cells (Chapin and Lamb, 1984). The Mean \pm SD of the testicular volume and volume occupied by seminiferous tubules was recorded as $0.98 \pm 15.10$ and $0.45 \pm 25.18 \mathrm{~cm}^{3}$ for control and treated animals respectively. These results revealed a significant damage to the testicular tissue induced by the arsenic toxicity which is in line with the results of arsenic toxicity in male rats (Morakinyo et al., 2010). This study exposed a significant $(\mathrm{p}<0.05)$ decrease of individual Leydig cell volume in the arsenic treated rabbits as compared to the control group of the experimental animals. These results confirm the findings of previous studies in mice and rats (Chinoy et al., 2004; Pant et al., 2001).

\section{Conclusion}

Present study exposed the histomorphometric effects of arsenic on the testicular morphology subsequently it is concluded that arsenic induce male infertility by negatively affecting the testicular volume, Leydig cell population, volume of the individual Leydig cells and hence the functions of the reproductive system in rabbits. 


\section{Acknowledgement}

We gratefully acknowledge the financial support of ORIC, PMAS-Arid Agriculture University, Rawalpindi, for smooth conduct of this study.

Disclaimer: None.

Conflict of Interest: None.

Source of Funding: ORIC, PMAS-Arid Agriculture University, Rawalpindi, Pakistan

\section{References}

Ahmad I, Akhtar K and Hussain T, 2008. Arsenic induced microscopic changes in rat testis. Prof. Med. J. 15: 287-291.

Bancroft JD and Gamble M, 2008. Theory and Practice of Histological Techniques. 6th Ed. Churchill Livingstone, Elsevier. 33-53pp.

Biswas R, Poddar S and Mukherjee A, 2006. Investigation on the genotoxic effects of long-term administration of sodium arsenite in bone marrow and testicular cell in vivo using comet assay. J. Environ. Pathol. Toxicol. Oncol. 26(1): 29-37.

Chang SI, Jin B, Youn P, Park C, Park JD and Ryu DY, 2007. Arsenic induced toxicity and the protective role of ascorbic acid in mouse testis. Toxicol. Appl. Pharmacol. 218: 196-203.

Chapin RE and Lamb JC, 1984. Effects of ethylene glycol mono-ethyl ether on various parameters of testicular function in the F344 rats. Environ. Health Perspect. 57: 219-224.

Chinoy N, Tewari K and Jhala D, 2004. Fluoride and/or arsenic toxicity in mice testis with formation of giant cells and subsequent recovery by some antidotes. Fluoride. 37: 172-184.

Department For Environment, Food And Rural Affairs (DEFRA) and Environment Agency (EA), 2002. Contaminants in Soil: Collation of Toxicological Data and Intake Values for Humans. Arsenic (R\&D Publication TOX 1), Bristol, UK, Environment Agency.

Ghaffar A, Hussain R, Abbas G, Ahmad MN, Abbas A, Rahim Y, Younus M, Shahid M and Mohiuddin M, 2018. Sodium arsenate and/or urea differently affect clinical attributes, hemato-biochemistry and DNA damage in intoxicated commercial layer birds. Toxin Rev. 37:206-215

Ghaffar A, Hussain R, Aslam M, Abbas G and Khan A, 2016. Arsenic and urea in combination alters the hematology, biochemistry and protoplasm in exposed Rahu Fish (Labeo rohita) (Hamilton, 1822). Turk. J. Fish. Aquat. Sci. 16:289-96.

Ghaffar A, Hussain R, Noreen S, Abbas G, Chodhary IR, Khan A, Ahmed Z, Khan MK, Akram K, Ulhaq M, Ahmad N, Ali F and Niaz M, 2020. Dose and time-related pathological and genotoxic studies on thiamethoxam in fresh water fish (Labeo rohita) in Pakistan. Pak. Vet. J. 40: 151-156.

Gul ST, Ahamd I, Saleemi MK, Ahmad M, Ahmad L and Khan A, 2020. Toxico-pathological effects of thiamethoxam on hemato-biochemical and productive performance of commercial laying hens. Pak. Vet. J. 40: 449-454.

Hussain R, Ghaffar A, Abbas G, Jabeen G, Khan I, Abbas RZ, Noreen S, Iqbal Z, Chaudhary IR, Ishaq HM, Ghori MT and Khan A, 2020. Thiamethoxam at sublethal concentrations induces histopathological, serum biochemical alterations and DNA damage in fish (Labeo rohita). Toxin Rev. DOI: 10.1080/15569543.2020.1855655

Imran M, Cao S, Wan SF, Chen Z, Saleemi MK, Wang N, Naseem MN and Munawar J, 2020. Mycotoxins - a global one health concern: A review. Agrobiol. Rec. 2: 1-16.

Johnson L and Neaves WB, 1981. Age-related changes in the leydig cell population, seminiferous tubules and sperm production in stallions. Bio. Reprod. 24: 703-712.

Kahlown MA, Tahir MA and Sheikh AA, 2004. Water Quality Status in Pakistan: Second Report (2002 2003). Pakistan Council of Research in Water Resources, Islamabad, ISBN: 969-8469-13-3.

Kamble GB and Muley DV, 2000. Effect of acute exposure of endosulfan and chlorpyriphos on the biochemical composition of the freshwater fish, Sarotherodon mossambicus. Ind. J. Environ. Sci. 4(1): 97-102.

Latif M, Faheem M and Asmatullah, 2020. Study of oxidative stress and histo-biochemical biomarkers of diethyl phthalate induced toxicity in a cultureable fish, Labeo rohita. Pak. Vet. J. 40: 202-208.

Malik MA, Azam M and Saboor A, 2010. Water Quality Status of Upper KPK and Northern Areas of Pakistan. Pakistan Council of Research in Water Resources, Water Resources Research Centre, Peshawar, Ministry of Science and Technology, Pakistan. pp. 17.

Morakinyo AO, Achema PU and Adegoke QA, 2010. Effect of Zingiber Officinale (Ginger) on sodium arsenite induced reproductive toxicity in male rats. Afr. J. Biomed. Res. 13: 39-45. 
Moura AA and Erickson BH, 1997. Age-related changes in peripheral hormone concentrations and their relationships with testis size and number of Sertoli andgerm cell in yearling beef bulls. J. Reprod. Fert. Cambridge. 111(2): 183-190.

Mukherjee S and Mukhopadhyay P, 2009. Studies on arsenic toxicity in male rat gonads and its protection by high dietary protein supplementation. $\mathrm{Al}$ Ameen J. Med. Sci. 2: 73-77.

Naz S, Hussain R, Ullah Q, Chatha AMM, Shaheen A and Khan RU, 2020. Toxic effect of some heavy metals on hematology and histopathology of major carp (Catla catla). Environ. Sci. Pollut. Res. https://doi.org/10.1007/s11356-020-10980-0

Pant N, Kumar RP, Murthy C and Srivastava SP, 2001. Male reproductive effect of arsenic in mice. BioMetals. 14: 113-117.

Podgorski JE, Eqani SA, Musstjab AS, Khanam T, Ullah R, Shen H and Berg M, 2017. Extensive arsenic contaimination in high-pH unconfined aquifers in the Indus Valley. Sci. Adv. 3: e1700935.

Raza M, Fida H, Jin-Yong L, Muhammad SB and Kideok KD, 2017. Ground water status in Pakistan: A review of contamination, health risks, and potential needs. Crit. Rev. Environ. Sci. Technol. 47 (18): 1713-1762.

Rehman K, Fatima F, Waheed I and Akash MSH, 2018. Prevalance of exposure of heavy metals and their impact on health consequences. J. Cell. Biochem. 119: 157-184.

Samrana S, Ali I, Azizullah A, Daud MK and Gan Y, 2017. Arsenic-based pollution status in Pakistan. Ann. Agric. Crop Sci. 2(2): id1027.

Sanghamitra S, Hazra J, Upadhyay SN, Singh RK and Amal RC, 2008. Arsenic induced toxicity on testicular tissue of mice. Ind. J. Physiol. Pharmacol. 52: 84-90.

Sarkar M, Chaudhuri G, Chattopadhayay A and Biswas NM, 2003. Effect of sodium arsenite on spermatogenesis, plasma gonadotrophins and testosterone in rats. Asian J. Androl. 5: 27-31.

Shahid M, Khalid M, Dumat C, Khalid S, Niazi NK, Imran M, Bibi I, Ahmad I, Hammad HM and Tabassum RA, 2017. Arsenic Level and risk Assessment of groundwater in Vehari, Punjab Province, Pakistan. Expo. Health. DOI: 10.1007/s12403-017-0257-7.
Shaikh FH, Syed AS and Rehman A, 2018. Groundwater contamination and the risk of arsenic poisoning in Pakistan-Letter to the Editor. J. Pak. Med Assoc. 68(8): 1288.

Sharaf S, Khan MUR, Aslam A and Rabbani M, 2020. Comparative study of heavy metals residues and histopathological alterations in large ruminants from selected areas around industrial waste drain. Pak. Vet. J. 40: 55-60.

Sharma R and Garu U, 2011. Effects of lead toxicity on developing testes in Swiss mice. Univers. J. Environ. Res. Tech. 1(4): 390-398.

Shukla JP and Pandey K, 1984. Impaired spermatogenesis in arsenic treated freshwater fish, Colisa fasciatus (Bl. and Sch.). Toxicol. Lett. 21(2): 191-195.

Sohail MT, Aftab R, Mahfooz Y, Yasar A, Yen Y, Shaikh SA and Irshad S, 2019. Estimation of water quality, management and risk assessment in Khyber Pakhtunkhwa and Gilgit-Baltistan, Pakistan. Desalination Water Treat. (171): 105-114.

Tahir MA and Bhatti MA, 1994. Survey of Drinking Water Quality in the Rural Areas of Rawalpindi District. Pakistan Council of Research in Water Resources. Islamabad (Internal Report).

Verstraeten SV, Aimo L and Oteiza PI, 2008. Aluminium and lead: molecular mechanisms of brain toxicity. Arch. Toxicol. 82: 789-802.

Yang CY, Chang CC, Tsai SS, Chuan HY, Ho CK and $\mathrm{Wu} \mathrm{TN}, 2003$. Arsenic in drinking water and adverse pregnancy outcome in an arseniasisendemic area in northeastern Taiwan. Environ. Res. 91: 29-34.

Zubair M, Ahmed M, Ahmad N, Naveed MR, Idrees M, Sallam MA and Bashir MI, 2014. Toxic Effects of Arsenic on Reproductive Functions of Male rabbit and their amelioration with Vitamin E. Glob. Vet. 12: 213-218.

\section{Contribution of Authors}

Pasha RH \& Khan MA: Investigation, sampling, research methodology and writing of original draft Qureshi AS: Conceptualization and data collection

Ali A \& Rehman SU: Literature review and editing of manuscript 